\title{
Disparities in antimicrobial consumption and resistance within a country: the case of beta-lactams in Argentina
}

\author{
Silvia Boni, ${ }^{1}$ Gustavo H. Marin, ${ }^{1,2}$ Laura Campaña, ${ }^{1}$ Lupe Marin, ${ }^{2}$ Alejandra Corso, ${ }^{3}$ \\ Soledad Risso-Patron, ${ }^{1}$ Fernanda Gabriel, ${ }^{1}$ Valeria Garay, ${ }^{1}$ and Manuel Limeres ${ }^{1}$
}

Suggested citation Boni S, Marin GH, Campaña L, Marin L, Corso A, Risso-Patron S, et al. Disparities in antimicrobial consumption and resistance within a country: the case of beta-lactams in Argentina. Rev Panam Salud Publica. 2021; 45:e76. https://doi.org/10.26633/ RPSP.2021.76

ABSTRACT Objective. To describe bacterial resistance and antimicrobial consumption ratio at the subnational level in Argentina during 2018, considering beta-lactams group as a case-study.

Methods. Antimicrobial consumption was expressed as defined daily doses (DDD)/1000 inhabitants. Resistance of Escherichia coli, Streptococcus pneumoniae, Pseudomonas aeruginosa, Klebsiella pneumoniae and Staphylococcus aureus to beta-lactams was recorded. Resistance/consumption ratio was estimated calculating "R" for each region of Argentina, and this data was compared with other countries.

Results. The most widely consumed beta-lactams in Argentina were amoxicillin (3.64) for the penicillin sub-group, cephalexin (0.786) for first generation cephalosporins, cefuroxime (0.022) for second generation; cefixime (0.043) for third generation and cefepime $(0.0001)$ for the fourth generation group. Comparison between beta-lactams consumption and bacterial resistance demonstrated great disparities between the six regions of the country.

Conclusions. The case-study of Argentina shows that antimicrobial consumption and resistance of the most common pathogens differed among regions, reflecting different realities within the same country. Because this situation might also be occurring in other countries, this data should be taken into account to target local efforts towards better antimicrobial use, to improve antimicrobial stewardship programs and to propose more suitable sales strategies in order to prevent and control antimicrobial resistance.

Keywords Drug resistance, microbial; beta-lactams; Argentina.

Antimicrobial resistance (AMR), the ability of microorganisms to persist or grow in the presence of drugs designed to inhibit or kill them, is a natural biological phenomenon. However, several factors such as the misuse and overuse of antimicrobials have accelerated the emergence and spread of AMR (1).

Evidence shows that half of the prescriptions of antimicrobials (ATM) are related to an irrational or unnecessary use (2),

\footnotetext{
National Administration of Drugs, Food and Technology, Buenos Aires, Argentina

2 National University La Plata-CUFAR-CONICET, La Plata, Argentina $\triangle$ Gustavo

Marin, gmarin@med.unlp.edu.ar
}

whereby the indication does not correlate with the disease, the clinical presentation does not require any ATM, or diagnostic tests have discordant results (3).

Bacteria such as Klebsiella pneumoniae, Staphylococcus aureus, Streptococcus pneumoniae, and Escherichia coli involve complex AMR mechanisms and place substantial clinical and financial burden globally, often warranting the use of ATM considered "watch" or "reserve" groups according to the World Health

This is an open access article distributed under the terms of the Creative Commons Attribution-NonCommercial-NoDerivs 3.0 IGO License, which permits use, distribution, and reproduction in any medium, provided the original work is properly cited. No modifications or commercial use of this article are permitted. In any reproduction of this article there should not be any suggestion that PAHO or this article endorse any specific organization
or products. The use of the PAHO logo is not permitted. This notice should be preserved along with the article's original URL. Open access logo and text by PLoS, under the Creative Commons Attribution-Share Alike 3.0 Unported license. 
Organization (WHO) classification. AMR causes failure of empirical treatments, aggravates morbidity, increases mortality, and has negative impact on the costs of care because of ineffective ATM treatment (4).

Additionally, multidrug-resistant bacteria have had a notable increase in recent decades. Aggravating the global AMR threat is also the lack of new drug development by the pharmaceutical industry due to reduced economic incentives and challenging regulatory requirements. Thus, over the past three decades, no new family of antibiotics has been discovered (1).

For all the aforementioned reasons, AMR has become a serious and increasingly concerning public health threat, with enormous global health, social and political repercussions (1-5).

In 2015, the World Health Assembly approved a global action plan to combat AMR, recognizing it as a global health priority (6). A similar regional plan of action was later endorsed by the Pan American Health Organization (PAHO) Member States, highlighting the importance of raising awareness about AMR, optimizing the use of ATM, reducing the incidence of infection and the spread of resistant microorganisms, and ensuring a sustainable investment in the fight against AMR (7). Indeed, the increased detection and spread of carbapenemase-producing bacteria in Latin America and the Caribbean in recent years illustrates the seriousness of the urgency of addressing AMR and the permanent concern of countries to put regulations in place for ATM (8). In this regard, PAHO has long supported countries of the Region of the Americas in addressing AMR prevention and control (9). An important area of focus has been the development of national strategies for the rational ATM consumption (avoiding self-medication, dispensing without prescription and overuse), appropriate use (indication according to diagnosis), adequate use (correct use of routes, doses and duration) and reduction in costs associated with irrational use (10). Indeed, Countries with high antimicrobial consumption typically have high levels of AMR (11-15).

Over the years, Argentina has built an extensive network of laboratories for monitoring AMR in human health (WHONET-Argentina). This network is made up of 95 laboratories from the main state hospitals, local hospitals and the National Reference Laboratory at the Antimicrobial Service of the National Institute of Infectious Diseases (INEI), National Administration of Laboratories and from Institute of Health (ANLIS) "Dr. Carlos G. Malbrán" which also acts as the reference laboratory for the regional AMR Surveillance Network of Latin America (ReLAVRA) and for the Hospital Infection Surveillance Program of Argentina (VIDHA) (16). Given the importance of ATM misuse and overuse as key drivers of AMR, the Argentine Ministry of Health conducts annually a "survey of prevalence of hospital infections in Argentina" (ENPIHA) in critical and non-critical areas to collect key information on ATM consumption in the country (10). Entities such as the National Agri-food Health and Quality Service (SENASA) and the National Institute of Agricultural Technology (INTA) also collaborate to prevent AMR by promoting the development of infection prevention and control programs in facilities for animal production.

The aim of this study was to describe and increase the knowledge of ATM consumption and to compare this data with the level of bacterial resistance in Argentina, identifying any differences between the country regions in order to guide a prompt local public health action for the prevention and control of AMR.

\section{MATERIALS AND METHODS}

A descriptive, observational, retrospective drug utilization research study was conducted for drug consumption and resistance data analysis in each region of Argentina. ATM consumption data were compiled and analyzed from sales data for each product expended to outpatients in 24 Argentine provinces. This data source was provided by IQVIA, (former IMS Health \& Quintiles) which cover the ambulatory consumption; information completed with data provided directly from pharmaceutical companies sells, representing the universe of country consumption. All ATM medicines were assorted according to their ATC classification (17).

The study period was from January 1 to December 31, 2018, being the year for which the latest data on both consumption and resistance were available. In order to compare the level of consumption, ATM data consumption for years 2016 and 2017 were included in the analysis.

The study focused on the beta-lactams group since it was the most prescribed antimicrobial group. The results for beta-lactams consumption expressed as defined daily dose (DDD) per 1000 inhabitants were stratified for the analysis into penicillin+aminopenicillins (J01C), cephalosporins (J01D), monobactams (J01DF) and carbapenems (J01DH). All sales of theses ATM groups were considered in the analysis. Within each subgroup, active ingredients included in a pharmacological presentation used for ATM treatment in outpatients were also examined.

The study collected information about the following variables: type of ATM; consumption of ATM; DDD; population exposed to these antimicrobials; geographical territory in which consumption was registered; and percentage of resistance for the different ATM in each geographic area for pathogens with the highest prevalence of infections in the country (Escherichia coli, Streptococcus pneumoniae, Pseudomonas aeruginosa, Klebsiella pneumoniae and Staphylococcus aureus).

The level of resistance for each ATM was estimated by the AMR Surveillance Network WHONET method according to the national registry generated by the Malbrán Institute. The country territory was divided according to local geographical division guidelines: North (provinces of Jujuy, Salta, Catamarca, Chaco, Corrientes, Formosa, La Rioja, Santiago del Estero, Misiones, Tucumán); Center (Córdoba, Entre Ríos, Santa Fe); Buenos Aires (Buenos Aires province); CABA (Buenos Aires City); Cuyo (San Juan, San Luis, Mendoza); Patagonia (Río Negro, Neuquén, La Pampa, Chubut, Santa Cruz, Tierra del Fuego).

The type of ATM was classified according to WHO Anatomical Therapeutic Chemical (ATC) classification. Consumption of ATM was defined as DDD as per WHO definition (technical unit of measurement of drug consumption known as a defined daily dose, and which expresses the daily dose of a drug for its main indication in adults) in relation to the number of inhabitants that consumed those ATM. Hence, consumption was calculated considering this data and according to the following formulas:

1. Consumption in defined daily dose (DDD) per 1000 inhabitants per day (DID) of the drugs used for antimicrobial treatment in Argentina (17). The calculation was made for each medication and year of the period analyzed, according to the formula: 


$$
\mathrm{DID}=\frac{\begin{array}{c}
\text { overall grams consumed of each drug } \\
\times 1000 \text { inhabitants }
\end{array}}{\mathrm{DDD} \times \mathrm{N}^{\circ} \text { inhabitants } \times 365 \text { days }}
$$

DID was calculated by computerized methods using a program designed for this purpose.

2. Population exposed (PE) to drugs. It was calculated for each active principle in the period analyzed, according to the formula:

$$
\mathrm{PE}=\frac{\mathrm{DDD} \times \mathrm{N}^{\circ} \text { of inhabitants }}{1000}
$$

Where:

$D D D$ is the technical unit of measurement of drug consumption known as a defined daily dose, and which expresses the daily dose of a drug for its main indication in adults; DID expresses the number of inhabitants of every 1000 that consume a DDD every day of a certain drug; consumption refers to the quantity of medicines, in any of their forms of presentation, sold by the provincial warehouses to the health units for their use; and exposed population (PE) refers to the number of patients exposed to a certain medicine, calculated from the DID.

Results were grouped and stratified by federal regions due to their different historical, geographical, social, economic and sanitary situations, for better visualization and understanding. After recording AMR, values observed for each pathogen in each region were compared with levels of resistance and the antimicrobial consumption detected. Additionally, in order to compare results obtained for Argentinian regions information from Europe and other Latin American countries was incorporated into the analysis.

For statistical analysis, consumption was expressed in DDD/ DID and resistance was expressed in percentage of each pathogen resistance to each antimicrobial group. We used the open access software for statistical computing and graphics " $\mathrm{R}$ ", version 4.0.0, with its default package, tidyverse, and ggplot for the development of the graphs.

The research protocol was approved by the Scientific Research Commission Ethics Committee (A31-018). All the information was codified and extracted from a secondary database, making it impossible to identify the people involved. For this reason, the anonymity of the data was guaranteed at all times and all stages of the study.

\section{RESULTS}

Data extracted from the pharmaceutical industry during the study period allowed analyzing antimicrobials either by therapeutic groups or by medicines belonging to each of the groups. From this information it was possible to confirm that for the penicillin family, the most widely antimicrobial consumed in Argentina was amoxicillin (Table 1).

For cephalosporin groups, cephalexin was the most consumed antimicrobial from the first generation cephalosporins, cefuroxime from the second generation, ceftriaxone from the third generation and cefepime from the fourth generation; the consumption of fifth generation cephalosporins was very low (Table 1).

The only monobactam consumed was aztreonam. Although

\begin{tabular}{|c|c|c|c|c|}
\hline & \multirow[t]{2}{*}{ Type of beta-lactams } & \multicolumn{3}{|c|}{ Consumption per year } \\
\hline & & 2016 & 2017 & 2018 \\
\hline \multirow[t]{9}{*}{ Penicillin } & Amoxicillin & 4.21 & 4.08 & 3.64 \\
\hline & Amoxicillin/Clavulanic & 2.57 & 2.62 & 2.43 \\
\hline & Amoxicillin/Sulbactam & 0.062 & 0.057 & 0.049 \\
\hline & Ampicillin & 0.049 & 0.044 & 0.038 \\
\hline & Ampicillin/Sulbactam & 0.0001 & 0.00001 & 0.000002 \\
\hline & Phenoximethyl penicillin & 0.128 & 0.125 & 0.139 \\
\hline & Benzylpenicillin/Benzatine & 0.02 & 0.017 & 0.016 \\
\hline & Piperacillin/Tazobactam & 0.0002 & 0.0002 & 0.0002 \\
\hline & Sultamicillin & 0.009 & 0.009 & 0.009 \\
\hline \multirow[t]{15}{*}{ Cephalosporin } & Cefadroxyl $1^{\circ} \mathrm{G}$ & 0.111 & 0.107 & 0.097 \\
\hline & Cephalexin $1^{\circ} \mathrm{G}$ & 0.868 & 0.848 & 0.7867 \\
\hline & Cephalotin $1^{\circ} \mathrm{G}$ & 0.00014 & 0.00013 & 0.0001 \\
\hline & Cephazoline $1^{\circ} \mathrm{G}$ & 0.0003 & 0.0003 & 0.00029 \\
\hline & Cefoxitin $2^{\circ} \mathrm{G}$ & 0.000089 & 0.000063 & 0 \\
\hline & Cefuroxime $2^{\circ} \mathrm{G}$ & 0.04 & 0.039 & 0.022 \\
\hline & Cefixime $3^{\circ} \mathrm{G}$ & 0.0435 & 0.0442 & 0.0435 \\
\hline & Cefotaxime $3^{\circ} \mathrm{G}$ & 0.00007 & 0.00001 & 0.00001 \\
\hline & Ceftazidime $3^{\circ} \mathrm{G}$ & 0.00067 & 0.00055 & 0.00053 \\
\hline & Ceftazidime/Avibactam $3^{\circ} \mathrm{G}$ & 0 & 0 & 0.00002 \\
\hline & Ceftriaxone $3^{\circ} \mathrm{G}$ & 0.018 & 0.018 & 0.016 \\
\hline & Cefepime $4^{\circ} \mathrm{G}$ & 0.00018 & 0.000135 & 0.0001 \\
\hline & Ceftobiprole $5^{\circ} \mathrm{G}$ & 0 & 0 & 0.00003 \\
\hline & Ceftaroline $5^{\circ} \mathrm{G}$ & 0 & 0 & 0.000002 \\
\hline & Ceftolozane $/$ Tazobactam $5^{\circ} \mathrm{G}$ & 0 & 0.000071 & 0.000026 \\
\hline M & Aztreonam & 0.000007 & 0.000006 & 0.000006 \\
\hline \multirow[t]{3}{*}{ CPM } & Ertapenem & 0.0016 & 0.0015 & 0.0012 \\
\hline & Imipenem & 0.0002 & 0.0002 & 0.0002 \\
\hline & Meropenem & 0.00033 & 0.00031 & 0.00021 \\
\hline
\end{tabular}
its consumption was low, its use doubled in the last year studied
TABLE 1. Consumption of beta-lactamics in Argentina, 2016-2018

M: monobactam; CPM: carbapenems; G: generation

(DID 0.000183, 0.000197 and 0.000394 for 2016, 2017 and 2018 respectively) when data-source was only hospitals.

In the carbapenem group, consumption of imipenem and meropenem was similar throughout the study period (Table 1).

In relation to the bacterial resistance present in Argentina, data is shown according to the species of bacteria and based on the geographical region where the samples were obtained (Table 2).

\section{Escherichia coli}

The analysis of the resistance of E. coli to aminopenicillins in Argentina showed that it was still low compared to most European countries or other areas of the Americas, even in regions of high consumption such as in the capital region of CABA (Figure 1a). Countries with similar consumption to CABA, such as France, Spain, Bolivia, Brazil, or Greece, had higher resistance with regards to third generation cephalosporins; the group had a relatively low consumption throughout Argentina, although the level of resistance of E. coli was high in areas of CABA, the Central and Cuyo regions (similar to the data observed in Greece, Hungary or Romania) and certainly lower than other countries such as Italy $(28.7 \%)$, Slovakia $(30.1 \%)$, Bolivia $(33.9 \%)$, Cyprus (37.1\%), or Bulgaria (38.7\%) (Figure 1b). 


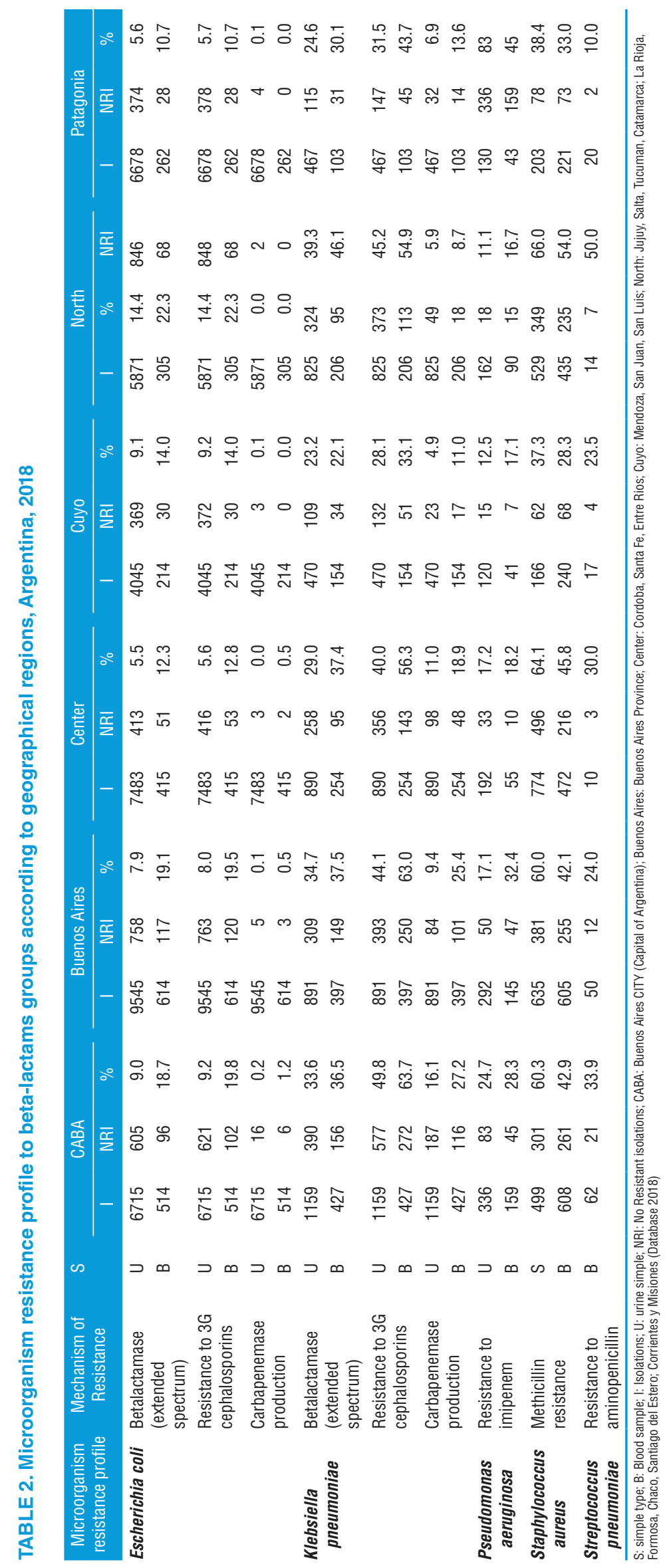


FIGURE 1. Escherichia coli: relationship between consumption and resistance according to geographic area, Argentina, 2018, and comparison with other countries. 1a: Consumption and resistance to aminopenicillins; 1b: Consumption and resistance to third generation cephalosporins; 1c: Consumption and resistance to carbapenems

$1 \mathrm{a}$

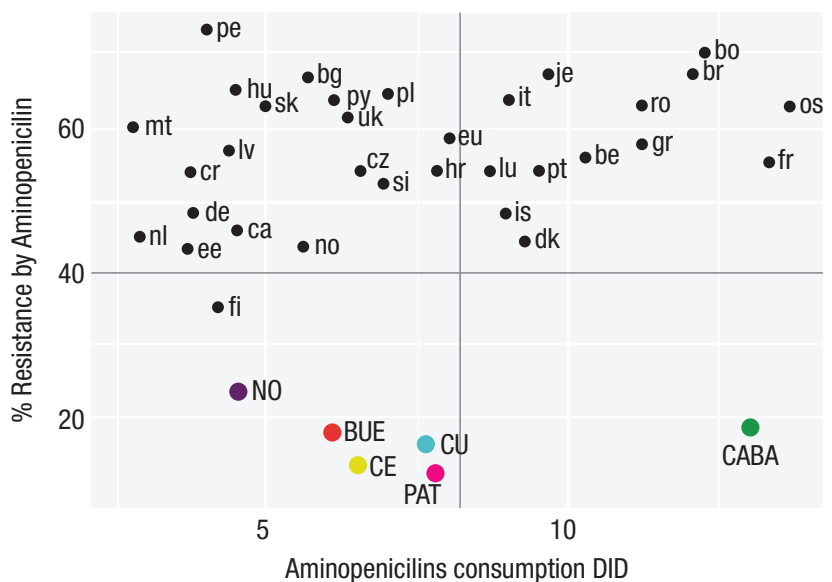

$1 \mathrm{c}$

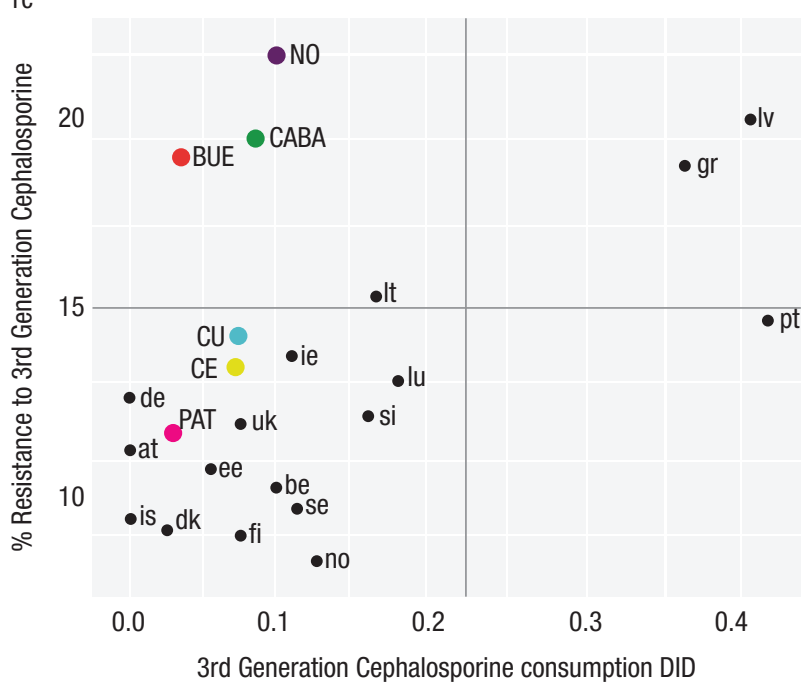

Note: countries are named with their Official Country Code (31)

With regard to the resistance of E. coli to carbapenem, findings were heterogeneous, with the resistance/consumption ratio still low for regions such as Patagonia, and high in the rest of Argentina (Figure 1c), with extremes such as in CABA (1.2 / 0.037), which has a similar reality to Greece, Cyprus, Bulgaria, or Peru, which exceeded the parameters configured in the graph's interface (Figure 1c).

\section{Klebsiella pneumoniae}

Resistance of Klebsiella pneumoniae to beta-lactams in general was high in CABA (similar to countries such as Romania); low in Cuyo (similar to Italy or Slovakia) and moderately resistant for the other regions of Argentina, Poland or Bulgaria (Figure 2a).

In Klebsiella pneumoniae, resistance to third generation cephalosporins was high despite their low consumption in all regions, a situation that was also observed in European countries such as Italy or Poland (Figure $2 b$ ).
$1 b$

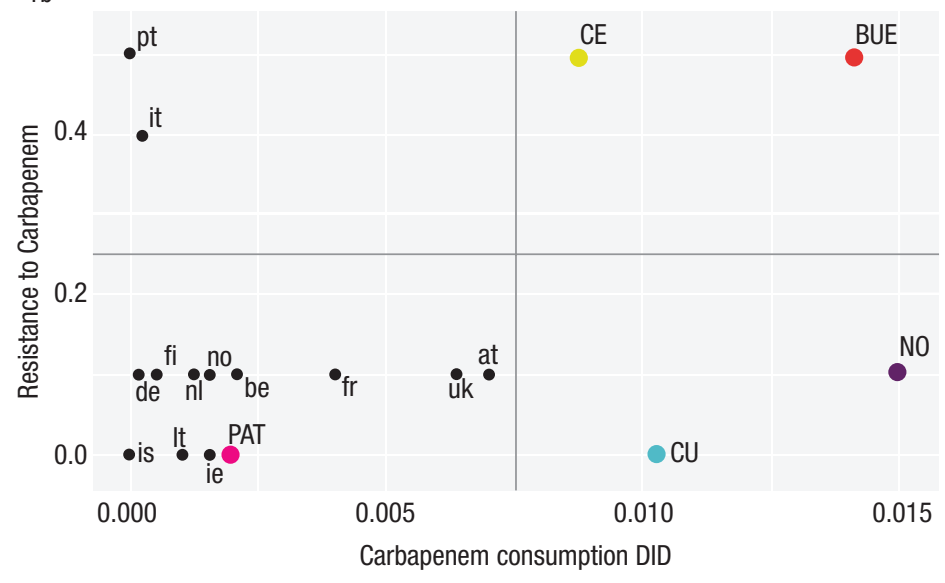

REGION

BUE: Buenos Aires

CE: Center

CABA: City of Buenos Aires

CU: Cuyo region

NO: North

PA: Patagonia
Klebsiella resistance to carbapenem and consumption of this group of antimicrobials was high in Buenos Aires and the Central region of Argentina (similar to that observed in Bulgaria) and relatively low in Patagonia, although clearly higher than that of Spain, Belgium or Denmark (Figure 2c).

\section{Pseudomonas aeruginosa}

Resistance to carbapenem and third generation cephalosporins in Pseudomonas aeruginosa was high in all regions of Argentina. With regards to carbapenem, we observed that some regions of Argentina had high resistance, similar to some European countries such as Greece, while regions such as Patagonia had similar patterns to Finland or the Netherlands (Figure 3a). The resistance/consumption relationship of P. aeruginosa for third generation cephalosporins was low in the Cuyo region, high in CABA and intermediate in the rest of Argentina (Figure 3b). 
FIGURE 2. Klebsiella pneumoniae: relationship between consumption and resistance according to geographic area, Argentina, 2018, and comparison with other countries. 2a: Consumption and resistance to third generation cephalosporins; $2 \mathrm{~b}$ : Consumption and resistance to carbapenems; $2 \mathrm{c}$ : Consumption and resistance to all beta-lactams

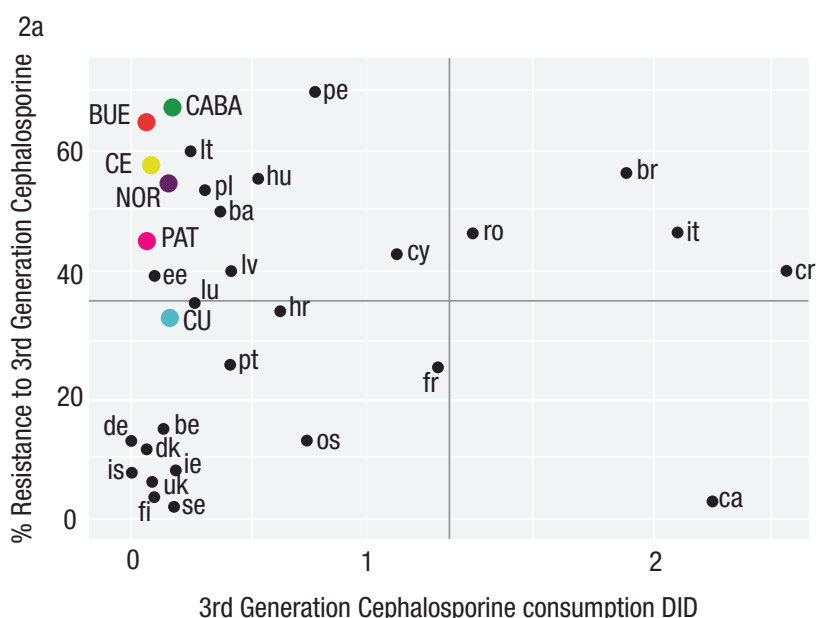

3rd Generation Cephalosporine consumption DID

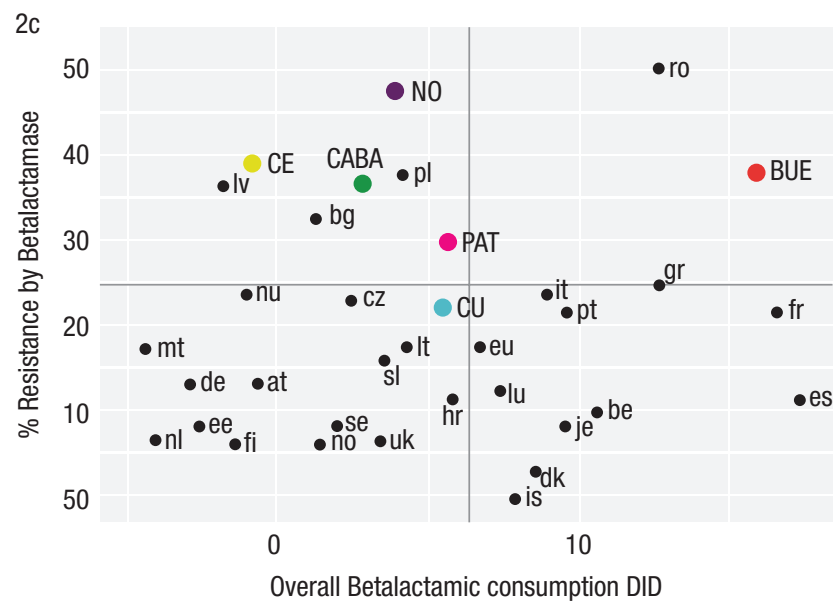

Note: countries are named with their Official Country Code (31)

\section{Staphylococcus aureus}

Methicillin resistance of Staphylococcus aureus was remarkably high in all regions of Argentina, whereas consumption was relatively low in comparison with countries of the region such as Brazil and Bolivia, and with European countries such as Italy, Greece and Romania (Figure 4a).

\section{Streptococcus pneumoniae}

The results obtained for Streptococcus pneumoniae showed that in all Argentina regions except Patagonia (10\%) there was high resistance to aminopenicillins (23.5-50.0\% depending on the region), resembling countries like France, Malta or Romania in Europe, or Costa Rica, Paraguay or Peru in the Americas. Consumption of aminopenicillins was high in CABA (similar to Belgium, France, Spain, Brazil or Bolivia); low in the North (similar to Scandinavian countries) and intermediate in the rest of the regions.

When the relationship between consumption and resistance was analyzed, it was high in CABA (similar to Romania), and
$2 b$

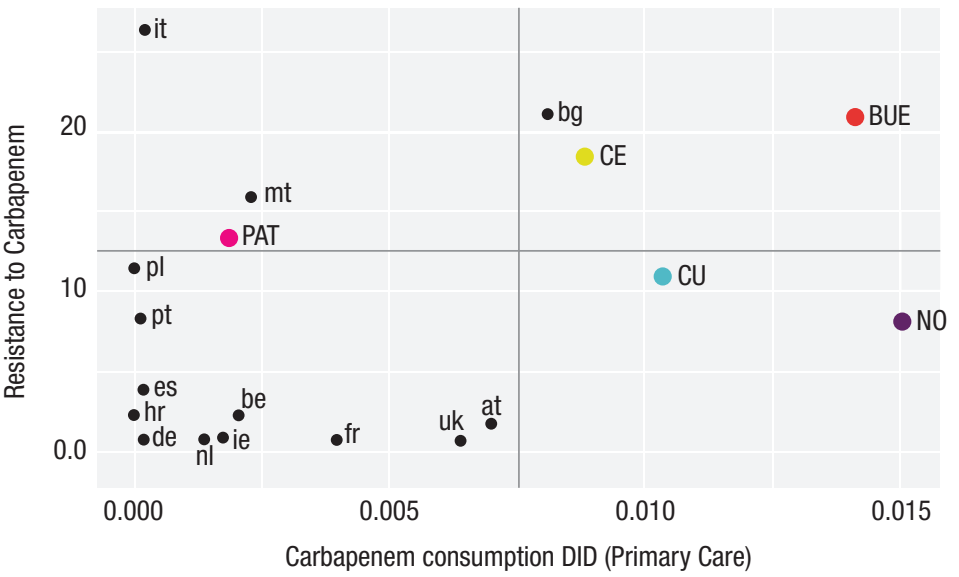

REGION

BUE: Buenos Aires

CE: Center

CABA: City of Buenos Aires

CU: Cuyo region

NO: North

PA: Patagonia decreased in the regions of Patagonia, Cuyo, Central or Buenos Aires (comparable to the UK or Brazil, Figure $4 b$ ).

\section{DISCUSSION}

Global evidence shows that antibiotic consumption has been usually low in high-income countries, whereas it has been disproportionally high in low and middle-income countries (1822). Although antibiotic consumption remained stable in many countries over the last 10 years (23); other studies demonstrated that the consumption rates for certain antimicrobials like cephalosporin decreased in high-income countries and increased in low and middle-income ones (24). Moreover, the prevalence of bacterial resistance generally correlated with the magnitude of antibiotic consumption in different Organization for Economic Cooperation and Development (OECD) countries (25).

Resistance to antibiotics has an ecological impact that transcends the patients receiving them, affecting the entire society. According to the declaration of the United Nations Assembly in 2016, "the development of resistance to antibiotics and the shortage of alternative treatments is the greatest chronic 
FIGURE 3. Pseudomonas aeruginosa: relationship between consumption and resistance according to geographic area, Argentina, 2018, and comparison with other countries. 3a: Consumption and resistance to carbapenems; 3b: Consumption and resistance to third generation cephalosporins
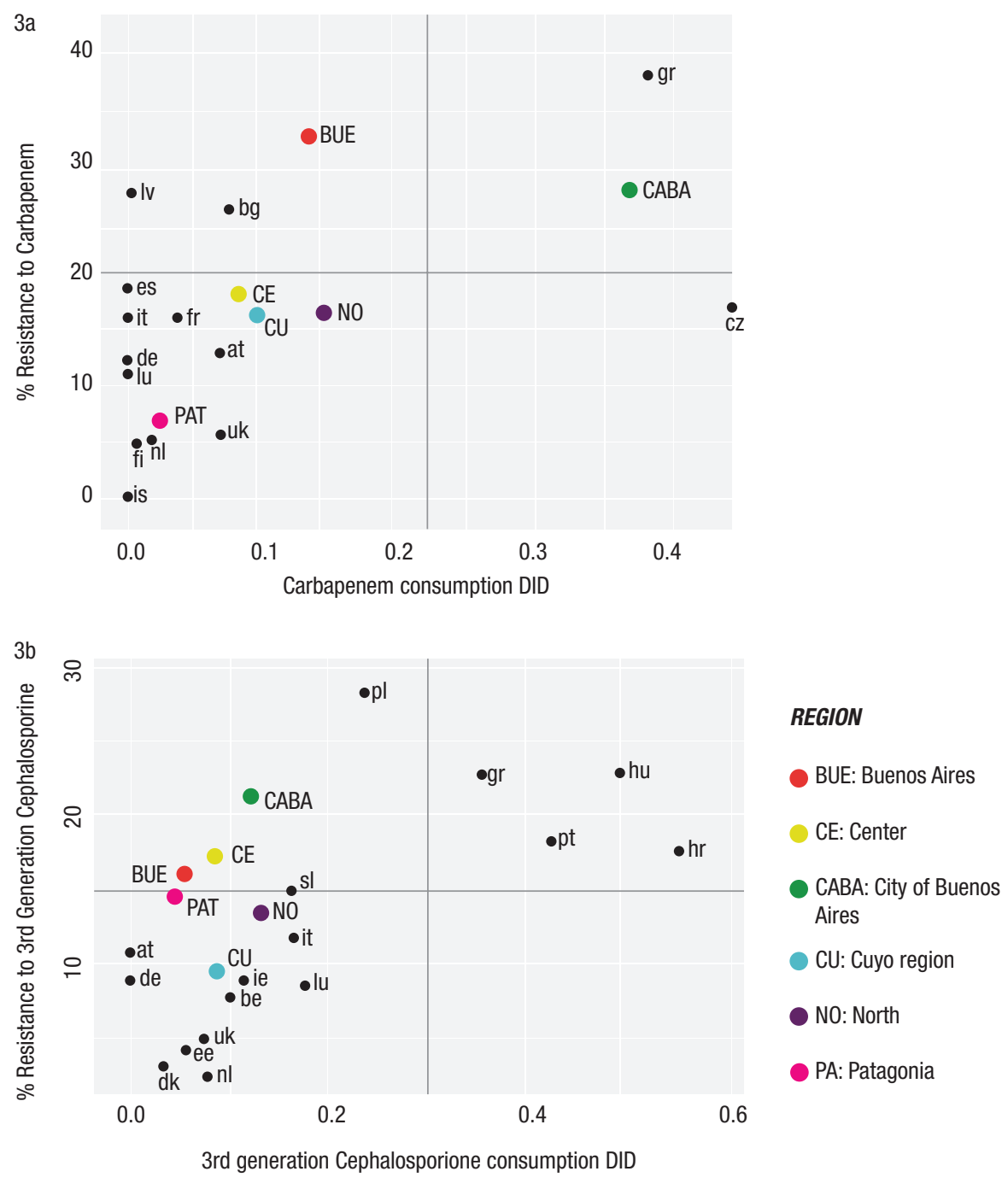

Note: countries are named with their Official Country Code (31)

problem that public health must face worldwide and requires greater attention and coherence at the international, national and regional level" (26).

Although the causes of AMR are multiple, one of the most important is the development of the biological self-defense mechanisms of bacteria, a process that has accelerated in recent years. However, this is a response of microorganisms to ATM exposure; for this reason, overconsumption and inappropriate use in humans are considered one of the main drivers of this situation (27).

Traditionally it has been considered that bacterial resistance originated in hospitals, but there is increasing evidence of the role of the community, where $93 \%$ of all antibiotics are consumed (28). However, even when the relationship between antimicrobial consumption in response to community-acquired infections and bacterial resistance is well known, data are scarce especially in developing countries $(28,29)$.

Austin et al. (22) showed the relationship between antimicrobial use and endemic resistance based on population genetic methods and epidemiologic observations, through the use of a unique population genetic framework, showing coexistence of resistant and the rate of antimicrobial consumption. It is clear that changes in antibiotic use patterns may reduce the frequency of resistance; however, these authors highlight that there is a critical level of drug consumption required to trigger the emergence of resistance to reach significant levels.

AMR data presented as part of our work came from mixed sources, and there was a predominance of information from hospital settings. This may explain some of the differences observed with other countries of the Americas or Europe.

The results of the present study showed that in Argentina it was detected a slight but progressive reduction in the consumption of beta-lactams in the last 3 years, while bacterial resistance levels varied according to the country region.

The results from the resistance/consumption analysis reflected a great disparity among the different country regions, suggesting several realities within Argentina.

This situation is also seen in other regions of the world. In Europe, antimicrobial bacterial resistance follows a north-south 
FIGURE 4. Staphylococcus aureus and Streptococcus pneumoniae: comparison between antimicrobial consumption and drugresistance, Argentina, 2018, and other countries. 4a: Consumption and resistance to cephalosporins; 4b: Consumption and resistance to aminopenicillins
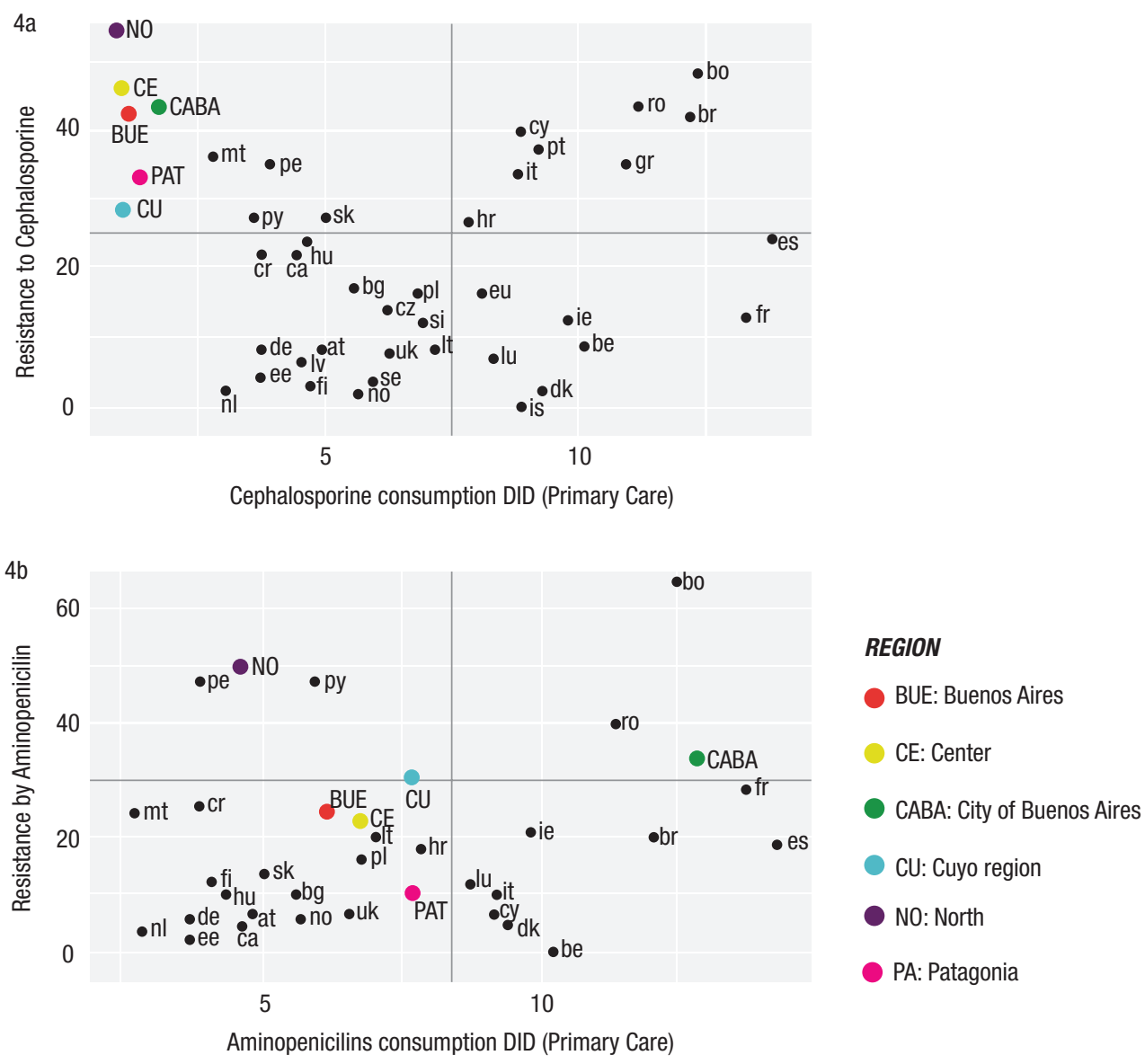

Note: countries are named with their Official Country Code (31)

gradient. Southern European countries have higher proportions of penicillin-non susceptible $S$. pneumoniae than countries in northern Europe, since the antimicrobial use tends to be higher in the south of that continent (18).

Following this pattern of disparities, and based on the results from our study, certain regions of Argentina resembled some northern European countries in terms of their level of antimicrobial consumption and their high bacterial resistance, while other regions resembled southern European, and other South American countries.

Regardless of the geographic location, it is clear that a responsible use of antibiotics both in the community and at hospital level has a crucial importance for the prevention of the spread of resistant pathogens.

Considering this data, this study shows a great variability of the ATM resistance/consumption ratio within the same country, which implies completely different realities within Argentina. Some regions of Argentina have cultural and economic similarities to the most developed countries of the world, while in other regions the situation resembles less developed countries. At the same time, the behavior of the population on the consumption of antimicrobials seems to accompany these local characteristics.
This data is an important issue to point out, since it reflects that national data from countries like Argentina with different realities within its territory might include information bias that should be considered when discussing local measures to control the irrational use of ATM or bacterial resistance in each region.

It was noteworthy that some very sparsely populated regions, such as Patagonia or the North, had an unusually high resistance/consumption ratio. For interpretation purposes, it should be taken into account that there is an indiscriminate use of antimicrobials for animal husbandry, an aspect that may explain this observation.

It is important to recognize that the main economic activity of Argentina is agricultural livestock, in which unfortunately there is an improper use of antimicrobials as growth promoters in poultry and cattle (30).

This study has some limitations. First, the lack of registration of the regional use of antimicrobial for indications other than human health. This represent an important bias, especially for countries such Argentina with great agricultural-livestock activity, where it is well known that the indiscriminate use of antibiotics for raising chickens, pigs, sheep and cattle constantly exposes the population to ATM, with a clear impact on bacterial resistance levels. Second, the method used to determine 
the consumption of antimicrobials contemplated a source of information that includes consumptions at both hospital and outpatient levels, an aspect that might be confusing at the time of analyzing and planning appropriate interventions in each region.

In conclusion, Argentina regularly provides data for global monitoring of AMR and ATM consumption; however, our analysis showed there are multiple realities within the country, which could also be occurring in other parts of the world. Since such data is used to inform policy and practices around the use of antimicrobials, our analysis highlights the importance of obtaining subnational and local data in order to take more effective measures that lead to better control of antimicrobial resistance. Our analysis of this case study of Argentina showed that both ATM consumption and resistance of the most common pathogens differ according to the country region, reflecting the potentially different realities that exist within the same country. Government-driven policies should consider these aspects in order to play a pivotal role in coordinating local efforts toward better antimicrobial use, professional antimicrobial stewardship programs and more suitable sales strategies in order to prevent and control AMR.

Authors' contributions. SB \& GHM conceived the original idea of the paper and wrote the manuscript; LC, SRP, FG, VG, ML \& AC collected the data of antimicrobial consumption and bacterial resistance; LM performed data analysis and interpreted the results. All authors reviewed and approved the final version.

Acknowledgment. Special thanks to Dr. Nathalie El Omeiri for her help in the manuscript revision and to Cloe Marin for her contribution in the design of the figures.

\section{Conflict of interest. None declared.}

Disclaimer. Authors hold sole responsibility for the views expressed in the manuscript, which may not necessarily reflect the opinion or policy of the RPSP/PAJPH and/or PAHO.

\section{REFERENCES}

1. World Health Organization. Combat drug resistance: no action today means no cure tomorrow. Statement WHO Director General, Dr Margaret Chan. Geneva; 2011. Available from: http://www. who.int/mediacentre/news/statements/2011/whd_20110407/en/ index. Accessed 6 April 2021.

2. Hecker MT, Aron Dc, Patel NP, Lehmann MK, Donskey CJ. Unnecessary use of antimicrobials in hospitalized patients: current patterns of misuse. Arch Intern Med. 2003;163(8):972-8.

3. President's Council of Advisors on Science and Technology. Report to the President on Combating Antibiotic Resistance. Washington D.C.: Executive Office of the President: 2014. Available from: https:/ / shea-online.org/images / / ThePolicyResourceCenter/ SupporttheSTAARAct/president.pdf. Accessed 1 April 2021.

4. Nathan C, Cars O. Antibiotic resistance-problems, progress, and prospects. N Engl J Med. 2014; 6;371(19):1761-3.

5. Chellat MF, Raguz L, Riedl R. Targeting antibiotic resistance. Angew Chem Int Ed Engl 2016; 55(23):6600-26

6. World Health Organization. Worldwide country situation analysis: response to antimicrobial resistance. Geneva: WHO; 2015. Available from: http://www.who.int/drugresistance/e. Accessed 1 April 2021.

7. Pan American Health Organization. $54^{\text {th }}$ Directing Council $67^{\text {th }}$ Session of the Regional Committee of WHO for the Americas. Plan of Action on Antimicrobial Resistance. Washington, DC: PAHO; 2015. Available from: https://www.paho.org/hq/dmdocuments/2015/ CD54-12-e.pdf.

8. Casellas JM. Resistencia a los antibacterianos en América Latina: consecuencias para la infectología. Rev Panam Salud Pública. 2011; 30(6):519-28. Accessed 1 April 2021.

9. Corso A, Guerriero L, Pasterán F, Ceriana P, Callejo R, Prieto M et al. Capacidad de los laboratorios nacionales de referencia en Latinoamérica para detectar mecanismos de resistencia emergentes. Rev Panam Salud Publica. 2011;30(6):619-26.

10. Peralta N, Camou B, Leszczuk K, Arcidiácono D, Lerena R, Herrera P, Fabre V. Prevalence of hospital antibiotic use in Argentina, 2018. Infect Control Hosp Epidemiol. 2019;40(11):1301-4.

11. LevyHara G, AmábileCuevas CF, Gould I, Hutchinson J, Abbo L, Saxinger L, et al. "Ten Commandments" for the appropriate use of antibiotics by the practicing physician in an outpatient setting. Frontier Microbiology. 2011;2:230.

12. Versporten A, Zarb P, Caniaux I, et al. Lancet Glob Health. 2018;6: 619-29.

13. Cižman M, Plankar Srovin T. Antibiotic consumption and resistance of gram-negative pathogens (collateral damage). GMS Infect Dis. 2018;9(6):5.
14. Pan American Health Organization. Resistencia a los antimicrobianos. Washington, DC: PAHO; 2020. Available from: https://www. paho.org/hq/index.php?option=com_docman\&view=list\&slug=r esistencia-a-antimicrobianos-5543\&Itemid=270\&lang=es. Accessed 9 April 2021.

15. Joseph NM, Bhanupriya B, Shewade DG, Harish BN. Relationship between Antimicrobial Consumption and the Incidence of Antimicrobial Resistance in Escherichia coli and Klebsiella pneumoniae Isolates. J Clin Diagn Res. 2015;9(2):DC08-DC12.

16. ANLIS. Manuales de procedimiento INEI. Normas técnicas, 2000 Buenos Aires, Argentina. Available from: http://sgc.anlis.gob.ar/ handle/123456789/585. Accessed 9 April 2021.

17. World Health Organization. Guidelines for ATC Classification and DDD assignment 2020. WHO-NIPH, Geneva: WHO; 2020. Available from: https:// www.whocc.no/filearchive/publications/2020_ guidelines_web.pdf. Accessed 9 April 2021.

18. European Center for Disease Prevention and Control. Antimicrobial consumption in the EU/EEA, annual epidemiological report for 2018. Stockholm: ECDC; 2019. Available from: https://www. ecdc.europa.eu/en/publications-data/surveillance-antimicrobialconsumption-europe-2018. Accessed 9 April 2021.

19. World Health Organization. WHO report on surveillance of antibiotic consumption: 2016-2018 early implementation. Geneva: WHO; 2018. Available from: https://www.who.int/medicines/ areas/rational_use/oms-amr-amc-report-2016-2018/en/ . Accessed 9 April 2021.

20. World Health Organization. Global antimicrobial resistance surveillance system (GLASS) report: early implementation 2020. Geneva: WHO; 2020. Available from: https://apps.who.int/iris/ handle/10665/332081. Accessed 9 April 2021.

21. Global WHO. Global Database for Antimicrobial Resistance Country Self-Assessment (2018-2019) Geneva: WHO. Available from: https://amrcountryprogress.org/8.

22. Austin DJ, Kristinsson KG, Anderson RM The relationship between the volume of antimicrobial consumption in human communities and the frequency of resistance. Proc Natl Acad Sci USA. 1999;96:1152-6.

23. Gianino MM, Lenzi J, Bonaudo M, Fantini MP, Ricciardi W, Damiani G. Predictors and trajectories of antibiotic consumption in 22 EU countries: Findings from a time series analysis (2000 \pm 2014$)$. PLoS ONE. 2018;13(6):e0199436. https://doi.org/10.1371/journal. pone. 0199436

24. Bronzwaer SL, Cars O, Buchholz U, et al. A European study on the relationship between antimicrobial use and antimicrobial resistance. Emerg Infect Dis. 2002;8(3):278-82. 
25. Cecchini M, Langer J, Slawomirski L. Antimicrobial Resistance in G7 Countries and Beyond: Economic Issues, Policies and Options for Action. Organization for Economic Co-operation and Development (OECD) 2015. Available from: https://www.oecd.org/els/ health-systems / Antimicrobial-Resistance-in-G7-Countries-andBeyond.pdf. Accessed 9 April 2021.

26. UN. At UN, global leaders commit to act on antimicrobial resistance. Collective effort to address a challenge to health, food security, and development, 2016. Available from: https://www. who.int/news/item/21-09-2016-at-un-global-leaders-commit-toact-on-antimicrobial-resistance. Accessed 9 April 2021.

27. Prestinaci F, Pezzotti P, Pantosti A. Antimicrobial resistance: a global multifaceted phenomenon. Pathog Glob Health. 2015; 109(7):309-18.

28. Davies J, Davies D. Origins and evolution of antibiotic resistance. Microbiol Mol Biol Rev. 2010;74(3):417-33.
29. Furuya E, Lowy F. Antimicrobial-resistant bacteria in the community setting. Nat Rev Microbiol. 2006;4:36-45.

30. Rodriguez E. Use of drugs in Argentina: A worrying issue. J Pharmacol Ther Res. 2018;2(1):6-8.

31. Eurostat. Glossary: Official Country codes. Available from : https:/ / ec.europa.eu/eurostat/statistics-explained/index.php/ Glossary:Country_codes

Manuscript received on 8 February 2021; revised version accepted for publication on 23 April 2021.

\section{Disparidades en el consumo de antimicrobianos y la resistencia a estos dentro de un país: el caso de los betalactámicos en Argentina}

RESUMEN Objetivo. Determinar la razón entre la resistencia bacteriana y el consumo de antimicrobianos a nivel subnacional en Argentina en el 2018, considerando el grupo de los betalactámicos como estudio de caso.

Métodos. El consumo de antimicrobianos se expresó como una dosis diaria determinada (DDD) por 1000 habitantes. Se registró la resistencia de Escherichia coli, Streptococcus pneumoniae, Pseudomonas aeruginosa, Klebsiella pneumoniae y Staphylococcus aureus a los betalactámicos. Se determinó la razón entre la resistencia y el consumo calculando "R" para cada región de Argentina, y estos datos se compararon con los de otros países.

Resultados. Los betalactámicos más consumidos en Argentina fueron la amoxicilina $(3,64)$ para el subgrupo de la penicilina; la cefalexina $(0,786)$ para las cefalosporinas de primera generación; la cefuroxima $(0.022)$ para las de segunda generación; la cefixima (0.043) para las de tercera generación, y la cefepima (0.0001) para el grupo de la cuarta generación. La comparación entre el consumo de betalactámicos y la resistencia bacteriana demostró que había grandes disparidades entre las seis regiones del país.

Conclusiones. El estudio de caso en Argentina indica que el consumo de antimicrobianos y la resistencia a los patógenos más comunes difería entre las regiones; esto demuestra que hay distintas realidades dentro del mismo país. Como esta situación también se puede dar en otros países, estos datos se deben tener en cuenta para definir las actividades locales destinadas a fomentar un mejor uso de los antimicrobianos, para mejorar los programas de manejo de los antimicrobianos y para proponer estrategias de venta más adecuadas con el fin de prevenir y controlar la resistencia a los antimicrobianos.

Palabras clave Farmacorresistencia microbiana; beta-lactamas; Argentina 


\section{Disparidades internas no consumo e na resistência aos antimicrobianos: o caso dos betalactâmicos na Argentina}

RESUMO Objetivo. Descrever a relação entre o consumo de antimicrobianos e a resistência bacteriana no nível subnacional na Argentina em 2018, considerando o grupo dos betalactâmicos no estudo de caso.

Métodos. O consumo de antimicrobianos foi representado por doses diárias definidas (DDD) por 1.000 habitantes. Foi registrada a resistência de Escherichia coli, Streptococcus pneumoniae, Pseudomonas aeruginosa, Klebsiella pneumoniae e Staphylococcus aureus aos betalactâmicos. A relação entre consumo e resistência foi calculada com base no "R" para cada região do país e os dados da Argentina foram comparados aos de outros países.

Resultados. Os betalactâmicos de maior consumo na Argentina foram amoxicilina $(3,64)$ no grupo das penicilinas, cefalexina $(0,786)$ no grupo das cefalosporinas de primeira geração, cefuroxima $(0.022)$ no grupo das cefalosporinas de segunda geração, cefixima (0.043) no grupo das cefalosporinas de terceira geração e cefepima (0.0001) no grupo das cefalosporinas de quarta geração. Ao se comparar o consumo de betalactâmicos e a resistência bacteriana, observou-se grande disparidade entre as seis regiões do país.

Conclusões. O estudo de caso revela diferenças no consumo de antimicrobianos e na resistência dos patógenos mais comuns entre as regiões da Argentina, refletindo realidades distintas dentro do mesmo país. Como esta mesma situação pode estar ocorrendo em outros países, estes achados devem servir para direcionar os esforços locais a uma melhor utilização dos antimicrobianos, aperfeiçoar os programas de gestão do uso destes medicamentos e propor estratégias de venda mais apropriadas, visando a prevenir e controlar a resistência aos antimicrobianos.

Palavras-chave Resistência microbiana a medicamentos; beta-lactamas; Argentina 